\title{
Polskiego filmu oświatowego dzieje nieznane
}

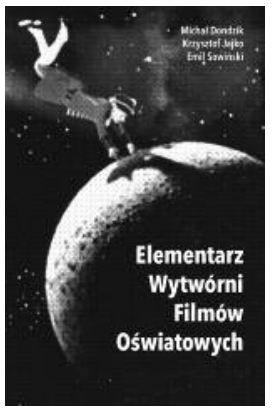

\author{
MARIUSZ GUZEK
}

W niektóre rejony dziejów kinematografii polskiej zapuszczamy się bardzo niechętnie. Prymat filmu fabularnego nad innymi rodzajami komunikacji audiowizualnej jest oczywisty i ta prosta konstatacja niestety wielokrotnie prowadziła w badaniach filmoznawczych do całkowitego lekceważenia innych filmów niż fikcjonalny obieg filmów. Jak bardzo ułomna była ta perspektywa, ukazuje wydany niedawno tom trzech autorów, którzy jego edycją debiutowali jako monografiści ${ }^{1}$. Michał Dondzik, Krzysztof Jajko i Emil Sowiński są jednak doskonale znani wśród filmoznawczego cechu. Ich wystąpienia konferencyjne, publikacje rozproszone, uczestnictwo w grantach indywidualnych i zespołowych, a przede wszystkim zainteresowania naukowe idące w poprzek modnym postulatom badawczym kazały niedługo czekać na efekt. W podręcznej bibliotece niejednego kinofila mogą się znajdować książki Macieja Łukowskiego o filmie etnograficznym zawierające omówienie produkcji oświatowej, nierzadko z wykazami filmów wyprodukowanych w WFO ${ }^{2}$, prace Zbigniewa Czeczota-Gawraka poświęcone filmowi o sztuce ${ }^{3}$, niskonakładowe rozważania krytyczne odnoszące się do zagadnień gatunkowych ${ }^{4}$ czy opasłe tomy panoramicznych opracowań kinematografii narodowej ${ }^{5}$, w których omawiano osiągnięcia łódzkiej Oświatówki. Publikacja trzech młodych naukowców łódzkich jest jednak jedynym (i to jednotomowym) kompleksowym opracowaniem obejmującym całość dziejów Wytwórni Filmów Oświatowych i szerzej polskiego filmu oświatowego, napisanym z dbałością o szczegóły, z poszanowaniem istniejących zasobów dokumentarnych i last but not least życzliwie dla czytelnika, który być może zachęcony recenzją rozpocznie przygodę $\mathrm{z}$ tym rodzajem polskiego filmu niefikcjonalnego.

Ponadto Elementarz Wytwórni Filmów Oświatowych mieści się w jeszcze jednym porządku badawczym. Autorzy nie ukrywają swojej afiliacji - wszyscy są związani z łódzkim środowiskiem akademickim i zaproponowana przez nich narracja jest kolejnym rozdziałem pisanej od kilku lat w rozmaitych projektach filmowej historii tego miasta ${ }^{6}$. Zaskakuje, i to bardzo pozytywnie, świadomość metodologiczna Dondzika, Jajki i Sowińskiego wyłuszczona w otwierającym tom dodatku do historii polskiej kinematografii. Ten wstęp to nie tylko inicjalny raport ze znajomości literatury przedmiotu, wyrażający przekonanie o błogosławieństwie żmudnych kwerend źródłowych, poszanowania drobnych tekstualnych i kontekstualnych znalezisk, ale przede wszystkim świadectwo polemicznego wyczucia, 
sugerujące spojrzenie na opisywany kompleks zjawisk procesualnie. Taka perspektywa zaprasza do negocjacji znaczeń, pozwala na oddanie emocji i poszanowanie wszystkich świadectw o istocie opisywanego segmentu dziejów filmowych. Jednak tak kompleksowe potraktowanie materii nieco utrudnia lekturę. Nadmiar szczegółów, analityczna egzegeza dokumentów (dostęp do nich nie był łatwy), dokładna, wręcz sprawozdawcza, chronologicznie ujęta rekonstrukcja mogą czytelnikowi nieprzyzwyczajonemu do opowieści produkcyjnych wydać się nieco monotonne, bądź na tyle mało istotne, by poświęcił im swój czas. Przestrzegam przed takim odbiorem. Warto bowiem przewertować (nawet kilka razy) karty rozprawy i wgryźć się w tajniki mikrokosmosu WFO - zapoznać się z jej sukcesami (jak nagrody przyznawane na międzynarodowych festiwalach branżowych Wieliczce Jarosława Brzozowskiego czy Archeologii Andrzeja Brzozowskiego), strategiami pozyskiwania autorów (bardzo ciekawy jest fragment poświęcony tzw. polityce otwartych drzwi Macieja Łukowskiego), rywalizacją z innymi podmiotami realizacyjnymi (głównie Wytwórnią Filmów Dokumentalnych i Telewizją Polską) czy rozpaczliwymi, czasami fantasmagorycznymi projektami ratowania wytwórni w latach zmiany ustrojowej. Po lekturze całej książki pojawi się oczywiste pytanie: czy tak musiały potoczyć się losy jednej z ważniejszych instytucji dla filmowego oblicza Łodzi, ale także polskiego filmu dokumentalnego? Autorzy wskazują różne przyczyny i w ich konkluzjach pobrzmiewają (pełne nostalgii i żalu) diagnozy, ale czynią to tak dyskretnie, by czytelnik (w tym także wystawiający im recenzyjną notę starszy kolega) mógł sam rozwiązać ten dylemat. Z jednym nie sposób się jednak zgodzić. Kiedy czytałem o osiągnięciach polskiego filmu oświatowego w dwudziestoleciu międzywojennym, odczuwałem brak choćby drobnej wzmianki o inicjatywach samorządowych, które przede wszystkim miały na celu utrwalenie wizerunku swoich miast w konwencji kina popularnownaukowego, krajoznawczego czy dydaktycznego. Co prawda są przywołania lokalnych projekcji, ale zabrakło mi bodaj jednego akapitu, który wskazałby na strategię budowania lokalnej celuloidowej tożsamości (a to przecież zadanie oświatowe) wśród mieszkańców Łodzi, Lwowa, Poznania czy Bydgoszczy. Pisali o tym przecież, oprócz Ireny Nowak-Zaorskiej, której fundamentalne opracowanie jest przywoływane we wstępie kilkukrotnie ${ }^{7}$, także filmowi regionaliści, a więc warto było skorzystać z ich ustaleń. Szkoda też, że autorzy nie wspomnieli o licznych inicjatywach oświatowych w okresie poprzedzającym istnienie niepodległego państwa, czemu osobiście poświęciłem sporo miejsca w monografii rekonstruującej polskie życie filmowe w okresie pierwszej wojny światowej ${ }^{8}$. Rozumiem jednak, że te wychodzące poza zasadniczy zakres drobiazgi musiały być w tak obszernej pracy pominięte. Zatem proszę, by te zdawkowe uwagi potraktować jako obowiązkowe czepianie się wiecznie niezadowolonego recenzenta, w żaden sposób nieprzekładające się na bardzo dobrą ocenę całości omawianego przedsięwzięcia.

Po lekturze Elementarza ... wiem z całą pewnością, że kilkudziesięcioletnia historia Wytwórni Filmów Oświatowych nie była kulturowym marginesem czy ulokowanym gdzieś na obrzeżach polskiej produkcji filmowej ideologicznym naddatkiem produkcyjnym do repertuarowych fabuł, który interesował jedynie decydentów politycznych i sfrustrowanych dokumentalistów. WFO nie była też oczywiście zjawiskiem tworzącym agendę opowieści o polskim filmie powojennym i autorzy monografii nie usiłują czytelników przekonywać do tak skrajnych kon- 
kluzji. Wytwórnia z jednej strony stanowiła istotną część projektu artystycznego, który tylko w tak instytucjonalnie skonstruowanych ramach mógł być realizowany, a z drugiej była istotnym komponentem doświadczenia kinowego, które dzięki polityce dystrybucyjnej, polegającej na prezentowaniu dodatków filmowych, tworzyło rytuał uczestnictwa w seansach repertuarowych. W poszczególnych rozdziałach napięcie między oczekiwaniami autorskimi a systemem realizacji obrazów niefikcjonalnych stanowi dominujący kierunek narracji.

Udało się też Dondzikowi, Jajce i Sowińskiemu zaprezentować dzieje Wytwórni Filmów Oświatowych w powiązaniu z szerszymi kontekstami społecznymi (pokusa skoncentrowania się tylko na instytucjonalnym aspekcie rekonstrukcji była ogromna), przede wszystkim jednak politycznymi, które determinowały nie tylko jej istnienie, ale też wpływały na reprezentacje gatunkowe, nadzór polityczny nad wytwórnią, wreszcie pojawienie się grupy twórców, dla których nie było miejsca w innych przestrzeniach narodowego przemysłu kinematograficznego. Taka koncepcja wpłynęła też na strukturę pracy, bowiem cezury wyznaczają wydarzenia (daleki byłbym od sugerowania terminu ,przełomy”) kojarzone najczęściej z ich wymiarem politycznym (lata 1949, 1954, 1968, 1980, 1989), ale skorygowane i dopasowane do dat właściwych dla środowiska oświatowo-filmowego, raczej niezwiązanych z niepokojami ustrojowymi (lata 1961, 1974, 1994, 2010). Zresztą uwarunkowania zarówno polityczno-ustrojowe, jak i branżowe tworzyły wspólną perspektywę, przez którą dzieje WFO powinny być czytane. Rozdziałów jest dwanaście. Trzy pierwsze odnoszą się do okresu 1945-1960, kiedy to formuła filmu oświatowego musiała znaleźć oparcie w systemie nowo organizującej się kinematografii narodowej. Do znanych z publikacji dokumentarnych epizodów związanych z krakowską Bazą Wytwórni Filmów Wojska Polskiego zostały dorzucone niezwykle ciekawe informacje tyczące absolutnie unikatowej w skali produkcyjnej żyrardowskiej pracowni jednego z pionierów polskiego filmu naukowego Karola Marczaka, uzupełnione o ustalenia odnoszące się do Działu Filmów Wąskotaśmowych, który jesienią 1945 r. powstał w Łodzi. Czytając te, jak i pozostałe strony omawianej książki, należy podkreślić kwestię absolutnie fundamentalną dla warsztatu historyka filmu, a szerzej historyka kultury. Autorzy nie udają, że poszczególne ustalenia są wyłącznie efektem ich kwerend, rozmów czy eksploracji zasobów bibliotecznych. Korzystając z wcześniejszych opracowań (niekoniecznie publikowanych), nie tylko odnotowują to w odnośnych przypisach bibliograficznych, ale także dokonują ich krytycznej oceny, nie stroniąc od uwag wartościujących (najczęściej pozytywnych). Szacunek dla poprzedników, ich pracy, efektów, z których można skorzystać, to cechy, które nie tylko należy docenić, ale potraktować jako kolejne świadectwo dojrzałego warsztatu badawczego. Zatem drobnym zgrzytem, jest pomyłka w oznaczeniu autorki dysertacji awansowej (pracy magisterskiej) zatytułowanej Działalność Filmów Oświatowych Instytutu Filmowego, z której korzystał, i co uczciwie zaznaczył, autor rozdziału Film oświatowy w zarodku - raz nazywana jest Krystyną Wągrowską, a innym razem prawidłowo Krystyną Zamysłowską (s. 29). Budowanie statusu instytucji, jaką była WFO, tworzy narrację pełną decyzji administracyjnych, prób reformy i wniosków mających umożliwić produkcję i uczynić codzienność zakładu pracy zatrudniającego kilkuset pracowników, reprezentujących rozmaite kategorie personelu medialnego, płynną i bezkonfliktową. Nie jest to jednak tylko „studium z kręgu produkcyjnego”. Dylematy 
administracyjne, jak zaksięgować wydatki na zakup nowych kamer czy renowację nienowoczesnych i wyeksploatowanych samochodów terenowych, zostały połączone z poszukiwaniami gatunkowymi, problematyką autorstwa, sztuką operatorską, wymiarem artystycznym filmu oświatowego, a wreszcie, co uważam za najcenniejsze, z pozostałymi komponentami polskiej kinematografii. Tak właśnie są skonstruowane kolejne części. Zresztą odbija się w nich specyfika poszczególnych epok - w latach 50. wyakcentowane są poszukiwania twórczych możliwości, 60. i 70. walka o umocnienie pozycji filmu oświatowego, a w ostatnich dekadach XX i pierwszych XXI w. rozpaczliwy bój o przetrwanie. Ważnym aspektem opowieści są ludzie Oświatówki. Pojawiają się weterani, których początki kariery sięgają kina szkolnego w dwudziestoleciu międzywojennym (z wielkim zainteresowaniem czytałem o losach Janusza Stara, który przed wojną zrealizował w moim rodzinnym mieście film Cała Bydgoszcz i jej mieszkańcy na ekranie, w WFO udanie eksperymentował z filmem „,kosmicznym”), młodzi adepci Filmówki, których później porwała magia kina fabularnego, wreszcie z rzadka wspominani klasycy dokumentu, wierni do końca kariery miejscu przy Kilińskiego 210. Zapewne dzięki wywołaniu źródeł w postaci wywiadów badawczych otrzymujemy nie tylko odnotowane w indeksowym załączniku imiona i nazwiska, ale pełnokrwiste postaci, co w opracowaniu naukowym nie jest takie częste.

Poza naturalnie skomponowaną strukturą pracy, respektującą przede wszystkim porządek chronologiczny (to zresztą błogosławieństwo dla prac wieloautorskich ${ }^{9}$ ) należy zauważyć, że apendyksy pomyślane jako uzupełnienia poszczególnych rozdziałów analizujące wybrane filmy powstałe w łódzkiej Oświatówce układają się w listę kanoniczną dla opisywanego zjawiska. Nie są to bynajmniej metryczki, z nazwiskami twórców czy krótkimi wzmiankami tyczącymi tematyki, ale dość rozbudowane narracje, w których Dondzik, Jajko i Sowiński starają się oddać emocje towarzyszące realizacjom (Wieliczka Jarosława Brzozowskiego), przywołać niepokoje związane z podjęciem drażliwej problematyki (Usłyszcie mój krzyk Macieja Drygasa) czy też oddać artystyczną, intelektualną, a także bardzo często eksperymentalną recepcję filmową (Bykowi chwała Andrzeja Papuzińskiego, Wanda Gościmińska - włókniarka Wojciecha Wiszniewskiego, Z mediomagnetycznego atelier Tytusa Czyżewskiego Józefa Robakowskiego). Kilkadziesiąt dwu-, trzystronicowych esejów tworzy tyleż studiów przypadku, minimonografii filmów zapomnianych i nawet w dzisiejszych warunkach trudnych do obejrzenia, ale czy przez to mniej istotnych? Część tych filmów została na szczęście (głównie dzięki TVP Kultura i kanałowi Kino Polska) w ostatnich dekadach uratowana od archiwalnego zapomnienia i takie tytuły, jak: Karmik Jankowy Wojciecha J. Hasa, Jak zapobiegać ciąży Romana Woźniakowskiego czy Szczurołap Andrzeja Barańskiego są w tej chwili dostępne na jedno internetowe kliknięcie.

Skoro jesteśmy przy wzmiankowanych tytułach (autorzy nie wahają się wobec niektórych z nich stosować identyfikatora ,arcydzieło”), to należy z aprobatą powitać pewien rodzaj gry stylistycznej, potraktowanej (tak się przynajmniej wydaje) jako uznanie dla jednego z najważniejszych reżyserów zarówno dla swojego pokolenia, jak i dla wytwórni. Tytułowy Elementarz to oczywiste odwołanie do wyprodukowanego w WFO filmu Wojciecha Wiszniewskiego tak właśnie zatytułowanego. W rozdziale 1980-1983. Stan przedwojenny $i$ wojenny, Elementarzowi został poświęcony zaledwie krótki akapit zawierający jego krótką prezen- 
tację: słynnym pułkownikiem WFO tego czasu byt „Elementarz”- ostatni krótkometrażowy film Wojciecha Wiszniewskiego. Film ten (jedno z najwybitniejszych dziet Wiszniewskiego) trafit do rozpowszechniania 15 grudnia 1980 roku, zdobywając wiele nagród (s. 251). Przywołałem ten fragment w całości, nie tylko dlatego, że jest lapidarny i nie zakłóca proporcji między moją oceną a cytowaną materią w artykule recenzyjnym, ale po to, aby dać próbkę metody narracyjnej stosowanej przez kolektyw autorski. W zasadniczych częściach pracy, czyli rozdziałach, unikali oni analitycznych uwag poświęconych strukturze filmów realizowanych w WFO, metodzie twórczej czy recepcji przywoływanego korpusu tytułów. Bardziej zajmowały piszących relacje między władzami kinematografii a kierownictwem wytwórni, trudności produkcyjne czy wreszcie problemy natury dystrybucyjnej, w rozmaitych okresach różnie (najczęściej w sposób niesatysfakcjonujący realizatorów) rozwiązywane. Na szczegółowe rozważania znajdowało się miejsce dopiero we wspomnianych powyżej apendyksach dołączonych do każdego chronologicznie skonstruowanego fragmentu. W tym poświęconym Elementarzowi jest sporo o intencjach Wiszniewskiego, egzegezie scenopisu i dyskusji kolaudacyjnej. Szkoda natomiast, że zabrakło odwołań do wcale licznej literatury filmoznawczej poświęconej zarówno temu reżyserowi, jak i jego sztandarowym dziełom wyprodukowanym w Oświatówce. Mam przede wszystkim na myśli tom opracowany przez poznańskie środowisko historyków filmu, w którym kilka artykułów wprost odnosi się do obrazów przywoływanych w książce Dondzika, Jajki i Sowińskiego ${ }^{10}$, a który przez autorów wykazujących przecież dość daleko posuniętą biegłość metodologiczną, nie został nawet odnotowany w bibliografii. To jednak tylko łyżka dziegciu, która nie zdołała zniszczyć smaku, jaki niewątpliwie towarzyszy lekturze recenzowanej monografii.

$\mathrm{Z}$ dużym zadowoleniem odnotowuję, że młodzi naukowcy łódzcy nie boją się korzystać z różnorodnych źródeł, łączyć ich dzięki krytycznemu osądowi w przekonującą całość, stawiając pytania i udzielając wiarygodnych, choć czasami intuicyjnych, odpowiedzi. Podstawową metodą jest zatem krytyczna analiza tekstów, zarówno prasowych, jak i dokumentarnych. Szczególnie wykorzystanie tych ostatnich wymagało nie lada wysiłku, przekopania tysięcy kart (zapewne czasami rozsypujących się w rękach badaczy) archiwum zakładowego WFO, ale i sięgnięcia po zasoby Archiwum Akt Nowych. Co do tych ostatnich, zapewne autorzy ubolewali, że nie mogli skorzystać z niedawno dopiero udostępnionego użytkownikom zespołu Głównego Urzędu Kontroli Prasy, Publikacji i Widowisk. Muszę ich jednak uspokoić - być może teczki zawierające ślady ingerencji cenzorskich w czasopiśmie „Film i Oświata” czy dotyczące filmu Anny Górnej Lekcja władzy, Antoniego Orwińskiego Naturyści lub Ryszarda Nakoniecznego Pociąg (takie odnalazłem podczas kwerendy w AAN) dodałyby nieco informacji o napięciu między wytwórnią a kontrolą ideologiczną, ale prawdopodobnie nie wpłynęłyby w znaczącym stopniu na ostateczny kształt książki.

$\mathrm{Na}$ zakończenie pozwolę sobie na refleksję osobistą. W drugiej połowie lat 90. współpracowałem z bydgoskim ośrodkiem TVP. Doskonale znałem operatorów, montażystów, kierowników produkcji i dziennikarzy tworzących młody, pełen entuzjazmu, choć jeszcze nieopierzony zespół twórczy. W pewnym momencie wśród personelu kierowniczego pojawiły się nowe osoby skierowane do Bydgoszczy przez szefostwo telewizyjnej Trójki. Wtedy nie dostrzegaliśmy żadnego profesjo- 
nalizmu realizacyjnego czy produkcyjnego, ale drażniła nas pycha, poczucie wyższości wobec prowincjonalnych pracowników telewizji i lekka ręka do wydawania pieniędzy na dość egzotyczne produkcje. Ryszard Nakonieczny i Zbigniew Grefkowicz - te nazwiska zapamiętałem i odnalazłem je na kartach recenzowanej książki. Cóż, może gdybym miał wynikającą z lektury Elementarza... wiedzę, nieco inaczej przed niemal ćwierćwieczem bym na nich spojrzał.

MARIUSZ GUZEK

Michał Dondzik, Krzysztof Jajko, Emil Sowiński, Elementarz Wytwórni Filmów Oświatowych, Wytwórnia Filmów Oświatowych, Łódź 2018.

${ }^{1}$ Michał Dondzik jako jedyny z tego grona ma na koncie samodzielnie opracowaną książkę, bardzo dobrze przyjętą przez recenzentów; zob. tenże, Leszek Wronko. Dźwięk filmu polskiego, Łódź 2013.

${ }^{2}$ M. Łukowski, Polski film etnograficzny, Warszawa 1987, s. 126-135.

3 Prof. Czeczot-Gawrak poświęcił filmowi o sztuce ponad dziesięć opracowań monograficznych, bibliografia w recenzowanej publikacji zawiera trzy jego książki: Film o sztuce: nowe zjawisko kultury artystycznej, Wrocław 1974; Filmowe spotkania ze sztuka, Warszawa 1974 i Filmowa prezentacja sztuki, Warszawa 1979.

${ }^{4}$ A. Iskierko, Znajomi z kina. Szkice o polskim filmie krótkometrażowym, Warszawa 1982. Filmowi oświatowemu jest poświęcony fragment rozdziału Polski film krótkometrażowy - szkic historyczny, s. 120-130 oraz część apendyksu zatytułowana Reżyserzy filmów oświatowych, s. 159-171.

${ }^{5} \mathrm{~W}$ tomach Historii filmu polskiego poświęconych powojennej kinematografii o filmie oświatowym pisały Irena Nowak-Zaorska (zob. Historia filmu polskiego. Tom III. 1939-1956, Warszawa 1974, s. 175-188, 281-295, 375-385; Historia filmu polskiego. Tom IV. 1957-1961, Warszawa 1980, s. 251-284) oraz Ewelina Nurczyńska-Fidelska (zob. Historia filmu polskiego. Tom V. 1962-1967, Warszawa 1985, s. 134-152; Historia filmu polskiego. Tom VI. 1968-1972, Warszawa 1994, s. 255-282). Ewelina Nurczyńska-Fidelska opracowała także część „oświatową" doprowadzoną do 1988 r. w jednotomowym monograficznym wydaniu Ency- klopedii kultury polskiej, zob. taż, Film oświatowy, w: Encyklopedia kultury polskiej. Film. Kinematografia, red. E. Zajiček, Warszawa 1994, s. 265-282.

${ }^{6}$ Dwóch autorów Elementarza... uczestniczyło w prowadzonym przez Ewę Ciszewską i Konrada Klejsę projekcie dotyczącym współczesnego oblicza filmowej Łodzi; zob. M. Dondzik, Przyczynek do historii Wytwórni Filmów Oświatowych w Lodzi (lata 1989-2014), w: Kultura filmowa współczesnej Łodzi, red. E. Ciszewska, K. Klejsa, Łódź 2015, s. 85-102; K. Jajko, Ludzie, paragrafy i elektronika. Łódzki ośrodek telewizyjny po 1989 roku, tamże, s. 105-126.

7 I. Nowak-Zaorska, Polski film oświatowy w okresie międzywojennym, Wrocław 1969, passim.

${ }^{8} \mathrm{M}$. Guzek, Co wspólnego z wojna ma kinematograf? Kultura filmowa na ziemiach polskich w czasie Wielkiej Wojny, Bydgoszcz 2014, s. 266-278.

${ }^{9}$ Jakkolwiek całość Elementarza Wytwórni Filmów Oświatowych jest podpisana przez trzech autorów, to na podstawie przypisów zawierających informacje o wywiadach badawczych można wywnioskować, który z rozdziałów został opracowany przez Michała Dondzika, który przez Krzysztofa Jajkę, a który przez Emila Sowińskiego.

${ }^{10}$ Są to m.in. teksty Katarzyny Mąki-Malatyńskiej , Wanda Gościmińska włókniarka”-demontaż filmowej nowomowy i Marka Hendrykowskiego „Elementarz” jako dokument artystyczny, w: Wojciech Wiszniewski, red. M. Hendrykowski, Poznań 2006, s. 109-120 i 121-140. 